\title{
DEVELOPMENT OF SOILS ON PARAGNEISS AND GRANITE IN THE SOUTHEASTERN PART OF BOHEMIA
}

\author{
Anna ŽIGOVÁ ${ }^{1) *}$, Martin ŠŤASTNÝ ${ }^{1)}$ and Radka KODEŠOVÁ ${ }^{2)}$ \\ 1) Institute of Geology, Academy of Sciences of the Czech Republic, v. v. i., Rozvojová 269, 16500 Prague 6- \\ Lysolaje, Czech Republic \\ 2) Department of Soil Science and Soil Protection, Faculty of Agrobiology, Food and Natural Resources, Czech \\ University of Life Sciences Prague, Kamýcká 129, 16521 Prague 6, Czech Republic \\ *Corresponding author's e-mail: zigova@gli.cas.cz
}

(Received September 2012, accepted February 2013)

\begin{abstract}
This study presents data about the effect of parent material on the intensity of processes that lead to the formation of a cambic subsurface horizon. The study was performed in the Voděradské bučiny National Nature Reserve with granite bedrock and in Humpolec with paragneiss bedrock. Representative soil profiles in the southeastern part of Bohemia were characterised on a macroscale level based on macromorphological description, particle size distribution, chemical, physical and soil organic matter properties. On the basis of the values of organic carbon and bulk density, the stock of soil organic matter was calculated in the upper $25 \mathrm{~cm}$ of soils. A more detailed characteristic of soil cover employed micromorphological and X-ray diffraction analyses. The results revealed differences in the formation of the cambic horizon on different types of parent material. The main soil forming process responsible for the cambic horizon is more intensive at localities with paragneiss bedrock.
\end{abstract}

KEYWORDS: parent material, cambic horizon, mineralogy, micromorphology, reserves of soil organic matter, soil formation

\section{INTRODUCTION}

Parent material is a starting point for the process of soil formation. The role of parent material in soil development can be studied within a scheme of the same soil type on different parent materials or different soil types on the same parent material. Soil development in the Czech Republic is predominantly connected with a high diversity of parent materials. Soils with a cambic horizon on different parent material cover $45.1 \%$ of agricultural land and $53.4 \%$ of forest land (Kozák et al., 2010).

Cambisols occur in all temperate and hydric conditions. Climate and parent materials are largely reflected in the intensity of the development of the cambic horizon. Most studies have focused on mineralogy of soils on granitic bedrock (Tardy et al., 1973; Sirový, 1974; Taboda and Garcia, 1999). Research on soil development on gneiss has been performed by Němeček (1974). Data on the mineral composition of soils with the cambic horizon developed on calcareous sandstone, paragneiss and orthogneiss were obtained by Žigová et al. (2010).

The purpose of this study is to compare the development of Cambisols on granite and paragneiss in conditions of natural and agricultural landscape on the basis of a broad range of analyses from macroscale to microscale level.

\section{MATERIAL AND METHODS}

The study area of Humpolec is located $102 \mathrm{~km}$ to the southeast of Prague. This locality lies in the area with average annual precipitation of $589 \mathrm{~mm}$ and average annual temperature of $7.0{ }^{\circ} \mathrm{C}$. The Moldanubian Zone dominated by metamorphic and igneous rocks is typical for this region. Chlupáč et al. (2002) described three groups of metamorphites. Tectonostratigraphy of the Moldanubian Zone sensu stricto is divided into the Gföhl, Drosendorf and Ostrong ("Monotonous Series") units. The Monotonous Series with biotite, biotite-muscovite and biotote-sillimanite paragneiss is typical for the study area. Near the contact with the Variscan granitic bodies, the paragneisses contain frequent cordierite. Data about the soil structure stability near the selected location were published by Kodešová et al. (2009). Soil conditions of this area are characterized on the basis of representative soil profiles Humpolec L and Humpolec PP.

The National Nature Reserve of Voděradské bučiny is located $30 \mathrm{~km}$ to the east of Prague. Climatic conditions of this area are characterised by average annual precipitation of $635 \mathrm{~mm}$ and average annual temperature of $7.3{ }^{\circ} \mathrm{C}$. This locality is situated in the northernmost part of the Central Bohemian Plutonic Complex whose youngest part is the Ríčany granite. Palivcová (1965) and Němec (1978) described the mineralogy of granites as a monotonous but also structurally variable. Biotite of the Ríčany granite (monzogranite) is often chloritized, and its feldspars are sometimes argillized or sericitized with grain size usually in the range $0.1-4 \mathrm{~mm}$. Xenocrysts are composed of orthoclase and reach $2-3 \mathrm{~cm}$ in size. The 
average grain size of the Jevany granite (syenogranite) is $0.4 \mathrm{~mm}$. Biotite grains in this type are sparsely distributed and reach a maximum size of $1 \mathrm{~mm}$. Some aspects of weathering of the Říčany granite and soil formation with the occurrence the $\mathrm{Bw}$ and $\mathrm{Gr}$ horizons were described by Minařík et al. (1998). Soil organisms such as micromycetes (Řepová, 1983) and soil and moss testate amoebae (Balík, 2001) were studied in the territory of the Voderadské bučiny National Nature Reserve. Soil cover of this locality is described from representative soil pits LP 35 and LP 36.

Selection of soil profiles was guided by a soil survey with a single gouge auger. The coordinates of soil profiles are given in the WGS 84 system; they were taken by GARMIN eTrex Summit. Soil profiles were excavated down to the $\mathrm{Cr}$ horizon. All samples were collected from soil horizons in soil pits. Morphological description and horizon designation was done according to Jahn et al. (2006). Individual soil profiles were classified according to the World Reference Base for Soil Resources (IUSS Working Group WRB, 2007). Colors were identified using the Munsell Soil Charts (2000).

Samples for micromorphological analyses were prepared from oriented aggregates impregnated with a polymer resin Epofix. The thin section was examined with the polarization microscope OLYMPUS BX51 with the digital camera DP70 using the Deep Focus 3.0 software. The terminology of Stoops (2003) was used for the description of thin sections.

Physical properties such as moisture, maximum capillary capacity, bulk density, particle density and porosity were measured in undisturbed core samples. Metal cylinders $100 \mathrm{~cm}^{3}$ in volume were pressed into the soil and measured using the standard method (Dane and Topp, 2002).

The particle size distribution, chemical properties and characteristics of soil organic matter except of hot-water extractable carbon were performed using standard methods (Valla et al., 2002). Particle size distribution was determined using the pipette method. The $\mathrm{pH}$ values were measured in distilled water and in $1 \mathrm{M} \mathrm{KCl}$ solution with a SenTix21 electrode using a soil:solution ratio of 1:2.5. Cation exchange capacity and exchangeable cations were determined using the Mehlich method. Organic carbon was determined by wet combustion with a mixture of potassium dichromate and sulphuric acid and total nitrogen using the Kjedahl method. Hot-water extractable carbon was done by Ghani (2003) with a minor modification by Krejčová (Žigová et al., 2007).

Mineral composition was studied in the fraction of $<0.001 \mathrm{~mm}$. Mineralogy of individual soil horizons was analysed using X-ray diffraction. Samples were prepared based on the methodology of Jackson (1975). Prior to the $\mathrm{X}$-ray analysis, soil organic matter was removed by $30 \% \mathrm{H}_{2} \mathrm{O}_{2}$. The samples were then washed four times with distilled water. Clay fraction was obtained using a sedimentation method, and oriented samples were prepared by carefully pipetting the clay suspension onto a glass slide and allowing it to dry at ambient temperature. Specimens were analysed in natural state, then saturated for four hours in ethylene glycol at $80{ }^{\circ} \mathrm{C}$ and heated at $550{ }^{\circ} \mathrm{C}$ for 4 hours. X-ray diffraction spectra were obtained on a Philips X'Pert diffractometer PW3020 equipped with $\mathrm{CuK} \alpha$ radiation, under a voltage of $40 \mathrm{kV}$ and intensity of $55 \mathrm{~mA}$. The XRD patterns were recorded at a goniometric shift $1{ }^{\circ} \cdot \mathrm{min}^{-1} 2 \Theta$. Semiquantitave values were calculated by K. Melka (oral information) based on the height of individual mineral basal peaks using correction coefficients.

\section{RESULTS AND DISCUSSION \\ MACROMORPHOLOGICAL CHARACTERISTICS OF SOIL PROFILES}

Four soil profiles located in the southeastern part of Bohemia and its main macromorphological properties were studied.

\section{Humpolec L}

Elevation: $506 \mathrm{~m}$ above sea level Coordinates: $49^{\circ} 33^{\prime} 27.3^{\prime \prime} \mathrm{N}, 15^{\circ} 21^{\prime} 00.9^{\prime \prime} \mathrm{E}$

Land use: permanent grass cover, herbage

Parent material: cordierite paragneiss

Ah: 0-17 cm, dark brown (10YR 3/3) moist and brown (10YR 5/3) dry, blocky subangular structure, loam texture, very friable consistence, very few rock fragments, very few small fragments of bricks, many fine roots, clear, smooth boundary

Bw: 17-49/69 cm, yellowish brown (10YR 5/6) moist and brownish yellow (10YR 6/6) dry, prismatic structure, sandy loam texture, friable consistence, common rock fragments, few fine roots, diffuse, broken boundary

Cr: 49/69-94 cm, brownish yellow (10YR 6/6) moist and very pale brown (10YR 7/4) dry, without structure, sandy loam texture, friable consistence, many rock fragments, approximately $40 \%$ of this horizon are composed of medium-weathered cordierite paragneiss, few very fine roots

\section{Humpolec PP}

Elevation: $528 \mathrm{~m}$ above sea level

Coordinates: $49^{\circ} 33^{\prime} 14.9^{\prime \prime} \mathrm{N}, 15^{\circ} 21^{\prime} 03.5^{\prime \prime} \mathrm{E}$

Land use: crop agriculture, barley

Parent material: paragneiss

Ap: 0-28 cm, very dark grayish brown (10YR 3/2) moist and pale brown (10YR 6/3) dry, cloddy structure, loam texture, friable consistence, very few rock fragments, very few small fragments of bricks, common fine roots, clear, smooth boundary

Bw: 28-61 cm, yellowish brown (10YR 5/6) moist and brownish yellow (10YR 6/6) dry, prismatic structure, clay loam texture, friable consistence, common rock fragments, few fine roots, few charcoal, clear, smooth boundary

Cr: 61-118 cm, light grayish brown (10YR 6/2) moist and very pale brown (10YR 7/3), without structure, 
loam texture, friable consistence, many rock fragments, approximately $40 \%$ of this horizon are composed of medium-weathered paragneiss, few very fine roots

\section{LP 35}

Elevation: $426 \mathrm{~m}$ above sea level

Coordinates: $49^{\circ} 58^{\prime} 32.3^{\prime \prime} \mathrm{N}, 1^{\circ} 46^{\prime} 38.1^{\prime \prime} \mathrm{E}$

Land use: nature preservation, beech forest

Parent material: Jevany type of granite

Oa: $0-10 \mathrm{~cm}$, very dark brown (10YR $2 / 2)$ moist and dark brown (10YR 3/3) dry, very weakly developed blocky subangular structure, sandy loam texture, noncoherent consistence, many fine and very fine roots, clear, smooth boundary

Ah: 10-27 cm, black (10YR 2/1) moist and very dark gray, (10YR 3/1) dry, blocky subangular structure, sandy loam texture, soft consistence, very few rock fragments, common fine roots, gradual, smooth boundary

AhBw: 27-51cm, brown (10YR 4/3) moist and light brownish gray (10 YR 6/2) dry, blocky angular structure, sandy loam texture, friable consistence, common rock fragments, few fine roots, clear, smooth boundary

Bw: 51-71 cm, strong brown (7.5YR 4/6) moist and reddish yellow (7.5YR 6/6) dry, prismatic structure, sandy loam texture, friable consistence, many rock fragments, few fine roots, clear, smooth boundary Cr: 71-111 cm, brownish yellow (10 YR 6/6) moist and very pale brown (10 YR 7/4) dry, without structure, sandy loam texture, very friable consistence, many rock fragments, approximately $60 \%$ of this horizon are composed of weakly weathered granite of Jevany type, few fine roots

\section{LP36}

Elevation: $479 \mathrm{~m}$ above sea level

Coordinates: $49^{\circ} 57^{\prime} 59.3^{\prime \prime} \mathrm{N}, 1^{\circ} 46^{\prime} 48.5^{\prime \prime} \mathrm{E}$

Land use: nature preservation, beech forest

Parent material: Ŕíčany type of granite

Ah: $0-8 \mathrm{~cm}$, black (10YR 2/1) moist and very dark brown (10YR 2/2) dry, very weakly developed blocky subangular structure, loam texture, very friable consistence, very few rock fragments, many fine roots, clear, smooth boundary

AhBw: 8-24 cm, brownish yellow (10YR 6/6) moist and yellow (10YR 7/6) dry, prismatic structure, loam texture, very friable consistence, few rock fragments, common fine roots, gradual, smooth boundary

Bw: 24-44 cm, strong brown (7.5YR 5/6) moist and reddish yellow (7.5YR 6/6) dry, prismatic structure, loam texture, very friable consistence, common rock fragments, few fine roots, clear, smooth boundary Cr: 44-58 cm, yellowish brown (10YR 5/4) moist and very pale brown (10YR 8/3) dry, without structure, sandy loam texture, very firm consistence, many rock fragments, approximately $60 \%$ of this horizon are composed of weakly weathered granite of Ríčany type, few fine roots
The pits of Humpolec L, Humpolec PP, LP 35 and LP 36 were classified as a Cambisol soil type. The occurrence of Oa horizon was documented in the case of soil profiles LP 35 and LP 36. Oa horizon of soil profile LP 36 is $1 \mathrm{~cm}$ thick. The thicknesses of A horizons of individual soils are different. Transitional horizon $\mathrm{ABw}$ was detected only in the soils with granitic bedrock. Thickness of $\mathrm{Bw}$ horizon is higher in soil developed on paragneiss. Morphological analysis showed that the thickness of A horizons is connected with the character of land use. The thickness of Bw horizons and the content of rock fragments are probably influenced by the type of parent material.

\section{MICROMORPHOLOGICAL CHARACTERICS OF SOIL PROFILES}

The distribution of main micromorphological properties in the soil profiles take given in Table 1 (Humpolec L), Table 2 (Humpolec PP), Table 3 (LP 35) and Table 4 (LP 36). Micromorphological analysis allowed to identify a variety of soil developments on paragneiss and granite. Cambisols on paragneiss have pedofeatures such as droppings of enchytraeids only in the case of $\mathrm{Ah}$ and Ap horizons. Bw horizons of these soils show highly separated subangular blocky microstructure with brownish yellow, speckled, granostriated b-fabric and close porphyric $\mathrm{c} / \mathrm{f}$ related distribution. The main components of groundmass are quartz and biotite. Apatite and ore minerals are present in small amounts. Cordierite was documented only in soil profile Humpolec L. The intensity of chemical weathering is higher in soils on cordierite paragneiss than in those on paragneiss. Cr horizons of these soils are also characterized by fragments of paragneiss. Cambisols on granite have pedofeatures such as droppings of enchytraeids and pellets of oribatid mites only in the case of $\mathrm{Oa}$ and Ah horizons. Bw horizons of these soils show moderately separated subangular blocky microstructure with strong brown speckled parallel striated b-fabric and open porphyric $\mathrm{c} / \mathrm{f}$ related distribution. The main component of groundmass is quartz. Biotite, plagioclase and ore minerals are present in small amounts. The soil on granite of the Ŕićany type shows a better developed $\mathrm{Bw}$ horizon than that on granite of the Jevany type. $\mathrm{Cr}$ horizons also typically contain fragments of granite. The results showed some variability in soil processes of humification and formation of the cambic horizon on different parent materials. The moder form of humus was classified in the case of $\mathrm{Oa}$ horizons. Differences in A horizons are controlled by the land use and character of vegetation. The analysis of thin sections of $\mathrm{Bw}$ horizons showed the dominance of quartz and biotite in soils on paragneiss and the dominance of quartz in soils on granite. The soils on paragneiss show a higher intensity of chemical weathering than those on granite. Micromorphological data showed different levels of weathering of parent material in the $\mathrm{Cr}$ horizons. 
Table 1 Micromorphological features of profile Humpolec L

\begin{tabular}{|c|c|c|c|}
\hline Humpolec L & $0-17 \mathrm{~cm}$ & $17-49 / 69 \mathrm{~cm}$ & 49/69-94 cm \\
\hline Microstructure & $\begin{array}{l}\text { moderately separated } \\
\text { angular blocky with } \\
\text { channels }\end{array}$ & $\begin{array}{l}\text { highly separated subangular } \\
\text { blocky with planes }\end{array}$ & bridged grain with few planes \\
\hline \multirow{2}{*}{$\begin{array}{l}\text { Groundmass } \\
\text { coarse material } \\
\text { mineral }\end{array}$} & & & \\
\hline & $\begin{array}{l}\text { angular grains of quartz } \\
\text { (fs-cs), biotite (fs-ms), } \\
\text { small portion of } \\
\text { muscovite (fs-ms), } \\
\text { plagioclase (fs-ms), } \\
\text { cordierite (fs) and ore } \\
\text { minerals (fs) }\end{array}$ & $\begin{array}{l}\text { angular grains of quartz (fs- } \\
\text { cs), biotite (fs-ms), small } \\
\text { portion of cordierite (fs), } \\
\text { apatite and ore minerals (fs) }\end{array}$ & $\begin{array}{l}\text { angular grains of quartz (cs), } \\
\text { biotite (cs), small portion of } \\
\text { cordierite (fs) and ore minerals } \\
\text { (fs), fragments of cordierite } \\
\text { paragneiss (cs) }\end{array}$ \\
\hline organic & $\begin{array}{l}\text { few remains of root } \\
\text { sections }\end{array}$ & & \\
\hline micromass & $\begin{array}{l}\text { very dark brown, dotted, } \\
\text { undifferentiated b-fabric }\end{array}$ & $\begin{array}{l}\text { brownish yellow, speckled, } \\
\text { granostriated b-fabric }\end{array}$ & $\begin{array}{l}\text { pale brown, speckled, } \\
\text { granostriated b-fabric }\end{array}$ \\
\hline $\begin{array}{l}\mathrm{c} / \mathrm{f} \text { related } \\
\text { distribution }\end{array}$ & close enaulic & close porphyric & gefuric \\
\hline Pedofeatures & $\begin{array}{l}\text { small portion droppings } \\
\text { of enchytraeids }\end{array}$ & & \\
\hline
\end{tabular}

fs - fine sand size, $\mathrm{ms}$ - medium sand size, cs - coarse sand size

Table 2 Micromorphological features of profile Humpolec PP.

\begin{tabular}{|c|c|c|c|}
\hline Humpolec PP & $0-28 \mathrm{~cm}$ & $28-61 \mathrm{~cm}$ & $61-118 \mathrm{~cm}$ \\
\hline Microstructure & $\begin{array}{l}\text { moderately separated } \\
\text { angular blocky with } \\
\text { packing }\end{array}$ & $\begin{array}{l}\text { highly separated subangular } \\
\text { blocky with planes }\end{array}$ & bridged grain with few planes \\
\hline \multicolumn{4}{|l|}{$\begin{array}{l}\text { Groundmass } \\
\text { coarse material }\end{array}$} \\
\hline mineral & $\begin{array}{l}\text { angular grains of quartz } \\
\text { (ms), biotite (fs), small } \\
\text { portion of ore minerals } \\
\text { (fs) }\end{array}$ & $\begin{array}{l}\text { angular grains of quartz } \\
\text { (ms-cs), biotite (ms-cs), } \\
\text { small portion of apatite and } \\
\text { ore minerals (fs) }\end{array}$ & $\begin{array}{l}\text { angular grains of quartz (ms-cs), } \\
\text { biotite (ms-cs), small portion of } \\
\text { ore minerals (fs), fragments of } \\
\text { paragneiss (cs) }\end{array}$ \\
\hline organic & $\begin{array}{l}\text { few remains of } \\
\text { carbonized root section }\end{array}$ & & \\
\hline micromass & $\begin{array}{l}\text { dark brown, dotted and } \\
\text { speckled, undifferentiated } \\
\text { b-fabric }\end{array}$ & $\begin{array}{l}\text { brownish yellow, speckled, } \\
\text { granostriated b-fabric }\end{array}$ & $\begin{array}{l}\text { pale brown, speckled, } \\
\text { granostriated b-fabric }\end{array}$ \\
\hline $\begin{array}{l}\mathrm{c} / \mathrm{f} \text { related } \\
\text { distribution }\end{array}$ & close porphyric & close porphyric & gefuric \\
\hline Pedofeatures & $\begin{array}{l}\text { small portion droppings } \\
\text { of enchytraeids }\end{array}$ & & \\
\hline
\end{tabular}

fs - fine sand size, ms - medium sand size, cs - coarse sand size

\section{PARTICLE SIZE DISTRIBUTION}

The particle size distribution and texture classes of individual soil horizons are shown in Table 5 . These data are lacking in the case of Oa horizon of soil profile LP 35 and Ah horizon of soil pit LP 36, where relatively high content of soil organic matter was detected. The particle size distribution of the examined profiles showed a general tendency with prevailing particle size category of sand.

\section{PHYSICAL PROPERTIES}

Physical properties of soils are presented in Table 6. Moisture is a highly variable property connected with land use and other parameters. The 
Table 3 Micromorphological features of profile LP 35.

\begin{tabular}{|c|c|c|c|c|c|}
\hline LP 35 & $0-10 \mathrm{~cm}$ & $10-27 \mathrm{~cm}$ & $27-51 \mathrm{~cm}$ & $51-71 \mathrm{~cm}$ & $71-111 \mathrm{~cm}$ \\
\hline Microstructure & $\begin{array}{l}\text { weakly } \\
\text { separated } \\
\text { granular with } \\
\text { channels }\end{array}$ & $\begin{array}{l}\text { moderately } \\
\text { separated } \\
\text { granular with } \\
\text { channels }\end{array}$ & $\begin{array}{l}\text { moderately } \\
\text { separated angular } \\
\text { blocky with } \\
\text { channels and plains }\end{array}$ & $\begin{array}{l}\text { moderately } \\
\text { separated } \\
\text { subangular blocky } \\
\text { with planes }\end{array}$ & $\begin{array}{l}\text { bridged grain with } \\
\text { few planes }\end{array}$ \\
\hline \multicolumn{6}{|l|}{$\begin{array}{l}\text { Groundmass } \\
\text { coarse material }\end{array}$} \\
\hline mineral & $\begin{array}{l}\text { angular grains } \\
\text { of quartz (ms) }\end{array}$ & $\begin{array}{l}\text { angular grains } \\
\text { of quartz (ms), } \\
\text { small portion of } \\
\text { biotite (ms), } \\
\text { plagioclase (ms) } \\
\text { and ore minerals } \\
(\mathrm{ms})\end{array}$ & $\begin{array}{l}\text { angular grains of } \\
\text { quartz (ms), small } \\
\text { portion of biotite } \\
(\mathrm{ms}), \text { plagioclase } \\
\text { (ms-cs) and ore } \\
\text { minerals (ms) }\end{array}$ & $\begin{array}{l}\text { angular grains of } \\
\text { quartz (ms), small } \\
\text { portion of biotite } \\
\text { (fs-ms), } \\
\text { plagioclase (fs- } \\
\text { ms) and ore } \\
\text { minerals (ms) }\end{array}$ & $\begin{array}{l}\text { angular grains of } \\
\text { quartz (ms-cs), } \\
\text { small portion of } \\
\text { biotite (fs-ms), } \\
\text { plagioclase (fs-ms) } \\
\text { and ore minerals } \\
\text { (ms), fragments of } \\
\text { Jevany granite type } \\
\text { (cs) }\end{array}$ \\
\hline organic & $\begin{array}{l}\text { remains of root } \\
\text { sections, leaf } \\
\text { tissue fragments }\end{array}$ & & & & \\
\hline micromass & $\begin{array}{l}\text { very dark } \\
\text { brown, dotted, } \\
\text { undifferentiated } \\
\text { b-fabric }\end{array}$ & $\begin{array}{l}\text { dark brown, } \\
\text { dotted, } \\
\text { undifferentiated } \\
\text { b-fabric }\end{array}$ & $\begin{array}{l}\text { brown, dotted and } \\
\text { speckled, parallel } \\
\text { striated b-fabric }\end{array}$ & $\begin{array}{l}\text { strong brown, } \\
\text { speckled, parallel } \\
\text { striated b-fabric }\end{array}$ & $\begin{array}{l}\text { light brown, } \\
\text { speckled, parallel } \\
\text { striated b-fabric }\end{array}$ \\
\hline $\begin{array}{l}\mathrm{c} / \mathrm{f} \text { related } \\
\text { distribution }\end{array}$ & close enaulic & close enaulic & open porphyric & open porphyric & gefuric \\
\hline Pedofeatures & $\begin{array}{l}\text { pellets of } \\
\text { oribatid mites } \\
\text { and droppings } \\
\text { of enchytraeids }\end{array}$ & $\begin{array}{l}\text { small portion of } \\
\text { oribateid mites }\end{array}$ & & & \\
\hline
\end{tabular}

fs - fine sand size, ms - medium sand size, cs - coarse sand size

Table 4 Micromorphological features of profile LP 36.

\begin{tabular}{|c|c|c|c|c|}
\hline LP 36 & $0-8 \mathrm{~cm}$ & $8-24 \mathrm{~cm}$ & $24-44 \mathrm{~cm}$ & $44-58 \mathrm{~cm}$ \\
\hline Microstructure & $\begin{array}{l}\text { moderately separated } \\
\text { granular blocky with } \\
\text { channels }\end{array}$ & $\begin{array}{l}\text { moderately separated } \\
\text { angular blocky with } \\
\text { channels and planes }\end{array}$ & $\begin{array}{l}\text { moderately separated } \\
\text { subangular blocky } \\
\text { with planes }\end{array}$ & bridged grain with planes \\
\hline \multicolumn{5}{|l|}{$\begin{array}{l}\text { Groundmass } \\
\text { coarse material }\end{array}$} \\
\hline mineral & $\begin{array}{l}\text { angular grains of } \\
\text { quartz (ms), small } \\
\text { portion of biotite } \\
(\mathrm{ms}) \text {, plagioclase (ms) } \\
\text { and ore minerals (ms) }\end{array}$ & $\begin{array}{l}\text { angular grains of quartz } \\
\text { (ms-cs), small portion } \\
\text { of biotite (ms), } \\
\text { plagioclase }(\mathrm{ms}) \text { and } \\
\text { ore minerals }(\mathrm{ms})\end{array}$ & $\begin{array}{l}\text { angular grains of } \\
\text { quartz (ms-cs), small } \\
\text { portion of biotite } \\
\text { (ms), plagioclase (ms) } \\
\text { and ore minerals (ms) }\end{array}$ & $\begin{array}{l}\text { angular grains of quartz } \\
\text { (ms-cs), small portion of } \\
\text { biotite (ms), plagioclase } \\
\text { (ms-cs) and ore minerals } \\
\text { (ms), fragments of Řičany } \\
\text { granite (cs) }\end{array}$ \\
\hline organic & $\begin{array}{l}\text { remains of root } \\
\text { sections, leaf tissue } \\
\text { fragments }\end{array}$ & $\begin{array}{l}\text { few remains of root } \\
\text { sections }\end{array}$ & & \\
\hline micromass & $\begin{array}{l}\text { dark brown, dotted, } \\
\text { undifferentiated b- } \\
\text { fabric }\end{array}$ & $\begin{array}{l}\text { brown, dotted and } \\
\text { speckled, parallel } \\
\text { striated b-fabric }\end{array}$ & $\begin{array}{l}\text { strong brown, } \\
\text { speckled, parallel } \\
\text { striated b-fabric }\end{array}$ & $\begin{array}{l}\text { light brown, speckled, } \\
\text { parallel striated b-fabric }\end{array}$ \\
\hline $\begin{array}{l}\mathrm{c} / \mathrm{f} \text { related } \\
\text { distribution }\end{array}$ & close enaulic & open porphyric & open porphyric & gefuric \\
\hline Pedofeatures & $\begin{array}{l}\text { pellets of oribatid } \\
\text { mites and droppings } \\
\text { of enchytraeids }\end{array}$ & & & \\
\hline
\end{tabular}

fs - fine sand size, $\mathrm{ms}$ - medium sand size, cs - coarse sand size 
Table 5 Particle size distribution.

\begin{tabular}{lccccl}
\hline Locality & Depth & Clay & Silt & Sand & Texture class \\
& cm & $\%$ & $\%$ & $\%$ & \\
\hline Humpolec L & $0-17$ & 9.6 & 42.1 & 48.3 & loam \\
& $17-49 / 69$ & 10.1 & 36.3 & 53.6 & sandy loam \\
& $49 / 69-94$ & 9.0 & 25.9 & 65.1 & sandy loam \\
\hline Humpolec PP & $0-28$ & 15.4 & 42.9 & 41.7 & loam \\
& $28-61$ & 28.5 & 36.1 & 35.4 & clay loam \\
& $61-118$ & 20.6 & 33.5 & 45.9 & loam \\
\hline LP 35 & $0-10$ & nd & nd & nd & nd \\
& $10-27$ & 8.3 & 18.6 & 73.1 & sandy loam \\
& $27-51$ & 4.9 & 24.7 & 70.4 & sandy loam \\
& $51-71$ & 5.7 & 21.5 & 72.8 & sandy loam \\
& $71-111$ & 4.4 & 25.8 & 69.8 & sandy loam \\
\hline LP 36 & nd & nd & nd & nd \\
& $8-24$ & 9.4 & 48.8 & 41.8 & loam \\
& $24-44$ & 10.5 & 45.7 & 43.8 & loam \\
$44-58$ & 10.2 & 19.7 & 70.2 & sandy loam \\
\hline
\end{tabular}

clay $-<0.001 \mathrm{~mm}$, silt $-0.001-0.05 \mathrm{~mm}$, sand $-0.05-2.00 \mathrm{~mm}$, nd - not determined

highest value of moisture was measured in the upper part of soil profiles in the case of permanent grass cover and the lowest moisture in the forest. The evaluation of maximum capillary capacity and retention water capacity was done by Valla et al. (2002). The value of maximum capillary capacity is relatively good in all soils. Data of retention water capacity are heterogeneous for each horizon of the individual soil profiles. Such distribution can be influenced by the size and type of rock fragments. The value of bulk density increases in the direction to the parent material with the exception of arable soil, where practically the same value was obtained in the whole profile. The highest bulk density was measured in Ap horizon of arable soil and the lowest in $\mathrm{Oa}$ horizon of the forest. Differences in bulk density in the upper part of forest soils were probably caused by different stages of litter decomposition. Particle density characterised the solid phase of soil without pores. This value is used for porosity calculation. Differences in particle density of the studied Cambisols are predominantly connected with the type of parent material and, in the case of A horizons, with the content of soil organic matter. Porosity is calculated from the bulk and particle density. The distribution of porosity in soil profiles has an opposite tendency to bulk density in all cases. Bulk density, porosity and particle size distribution were used for the evaluation of compaction soils by Lhotský (2000). These properties were analysed as critical for arable
Cambisol developed on paragneiss. The different physical properties of Cambisols developed on paragneiss are influenced by the type of land use. Cambisol developed on granite in forest conditions has better characteristics. Some dissimilarity in this condition in the upper part of the soil profiles are controlled by the quality of soil organic matter.

\section{SOIL CHEMICAL PROPERTIES}

Data on soil chemical properties are summarized in Table 7. The values of $\mathrm{pH}$ are very acid in soils at Humpolec and hyperacid in the Voděradské bučiny National Nature Reserve. Cation exchange capacity is the highest in the $\mathrm{O}$ and $\mathrm{A}$ horizons of all soils. The value of cation exchange capacity is relatively higher in soils developed on paragneiss. The content of exchangeable potassium, calcium and magnesium commonly depends on the type of parent material, and is higher in soil profiles at Humpolec. The values of base saturation do not exceed $21 \%$ in soil profiles in the Voděradské bučiny National Nature Reserve. These values range from 44 to $74 \%$ in soils on paragneiss whereas a higher base saturation was found on agricultural crop. A more detailed soil nomenclature of Cambisols was elaborated based on the chemical properties, especially on the values of base saturation. The soil profiles from Humpolec are classified as Haplic Cambisols. The soils studied in the Voděradské bučiny National Nature Reserve are covered with Dystric Cambisols. 
Table 6 Physical properties.

\begin{tabular}{lccccccc}
\hline Locality & Depth & M & MCC & RWC & BD & PD & P \\
& cm & $\%$ & $\%$ & $\%$ & $\%$ & $\%$ & $\%$ \\
\hline Humpolec L & $0-17$ & 43.90 & 50.94 & 45.25 & 1.08 & 2.48 & 56.45 \\
& $17-49 / 69$ & 44.70 & 40.37 & 34.06 & 1.36 & 2.62 & 48.09 \\
& $49 / 69-94$ & 18.85 & 26.59 & 17.79 & 1.58 & 2.68 & 41.05 \\
\hline Humpolec PP & $0-28$ & 28.66 & 38.84 & 35.04 & 1.59 & 2.55 & 37.65 \\
& $28-61$ & 33.29 & 37.64 & 33.55 & 1.61 & 2.68 & 39.93 \\
& $61-118$ & 31.88 & 36.99 & 32.84 & 1.63 & 2.67 & 38.95 \\
\hline LP 35 & $0-10$ & 15.17 & 43.01 & 36.77 & 0.22 & 1.58 & 86.07 \\
& $10-7$ & 40.29 & 55.62 & 48.93 & 0.48 & 1.75 & 72.57 \\
& $27-51$ & 13.94 & 31.60 & 23.29 & 1.44 & 2.55 & 43.53 \\
& $51-71$ & 12.73 & 34.44 & 27.80 & 1.36 & 2.59 & 47.49 \\
& $71-111$ & 13.20 & 22.08 & 14.84 & 1.35 & 2.59 & 47.88 \\
\hline LP 36 & $0-8$ & 21.69 & 30.10 & 26.89 & 0.85 & 2.18 & 61.00 \\
& $8-24$ & 22.96 & 41.68 & 36.77 & 1.26 & 2.56 & 50.78 \\
& $24-44$ & 15.65 & 31.20 & 22.44 & 1.32 & 2.59 & 49.03 \\
& $44-58$ & nd & nd & nd & nd & nd & nd \\
\hline
\end{tabular}

$\mathrm{M}$ - moisture, $\mathrm{MCC}$ - maximum capillary capacity, RWC - retention water capacity, BD - bulk density, $\mathrm{PD}$ - particle density, $\mathrm{P}$ - porosity, nd - not determined

Table 7 Chemical properties.

\begin{tabular}{|c|c|c|c|c|c|c|c|c|}
\hline Locality & $\begin{array}{c}\text { Depth } \\
\mathrm{cm}\end{array}$ & $\mathrm{pH}_{\mathrm{H} 2 \mathrm{O}}$ & $\mathrm{pH}_{\mathrm{KCl}}$ & $\begin{array}{c}\mathrm{CEC} \\
\mathrm{cmol} / \mathrm{kg}\end{array}$ & $\begin{array}{c}\mathrm{K}^{+} \\
\mathrm{cmol} / \mathrm{kg}\end{array}$ & $\begin{array}{c}\mathrm{Ca}^{2+} \\
\mathrm{cmol} / \mathrm{kg}\end{array}$ & $\begin{array}{c}\mathrm{Mg}^{2+} \\
\mathrm{cmol} / \mathrm{kg}\end{array}$ & $\begin{array}{c}\text { BS } \\
\%\end{array}$ \\
\hline \multirow[t]{3}{*}{ Humpolec L } & $0-17$ & 4.49 & 3.93 & 18.81 & 0.66 & 6.85 & 0.84 & 44 \\
\hline & $17-49 / 69$ & 4.72 & 4.03 & 11.12 & 0.13 & 4.75 & 0.46 & 48 \\
\hline & 49/69-94 & 4.72 & 3.96 & 6.99 & 0.10 & 3.19 & 0.38 & 53 \\
\hline \multirow[t]{3}{*}{ Humpolec PP } & $0-28$ & 5.09 & 4.53 & 17.95 & 0.51 & 9.51 & 1.18 & 62 \\
\hline & $28-61$ & 4.92 & 3.97 & 17.40 & 0.29 & 11.21 & 1.79 & 76 \\
\hline & $61-118$ & 4.43 & 3.37 & 21.43 & 0.37 & 12.65 & 2.77 & 74 \\
\hline \multirow[t]{5}{*}{ LP 35} & $0-10$ & 3.42 & 2.68 & 98.50 & 1.05 & 5.19 & 1.27 & 8 \\
\hline & $10-27$ & 3.00 & 2.20 & 86.70 & 0.22 & 0.93 & 0.66 & 2 \\
\hline & $27-51$ & 3.70 & 2.95 & 8.60 & 0.06 & 0.08 & 0.04 & 2 \\
\hline & $51-71$ & 4.05 & 3.70 & 11.50 & 0.06 & 0,06 & 0.02 & 1 \\
\hline & $71-111$ & 3.95 & 3.45 & 5.90 & 0.06 & 0.12 & 0.03 & 2 \\
\hline \multirow[t]{4}{*}{ LP 36} & $0-8$ & 3.94 & 3.22 & 45.52 & 0.53 & 3.18 & 0.54 & 9 \\
\hline & $8-24$ & 4.33 & 3.93 & 11.24 & 0.02 & 0.04 & 0.05 & 1 \\
\hline & $24-44$ & 4.31 & 4.12 & 8.40 & 0.01 & 0.04 & 0.05 & 1 \\
\hline & $44-58$ & 4.83 & 3.80 & 4.06 & 0.05 & 0.49 & 0.31 & 21 \\
\hline
\end{tabular}

CEC - cation exchange capacity, $\mathrm{K}^{+}$- exchangeable potassium, $\mathrm{Ca}^{2+}$ - exchangeable calcium, $\mathrm{Mg}^{2+}-$ exchangeable magnesium, $\mathrm{BS}$ - base saturation 
Table 8 Soil organic matter.

\begin{tabular}{|c|c|c|c|c|c|c|}
\hline \multirow[t]{2}{*}{ Locality } & Depth & $\mathrm{C}_{\mathrm{ox}}$ & $\mathrm{N}_{\mathrm{t}}$ & $\mathrm{C} / \mathrm{N}$ & $\mathrm{C}_{\mathrm{hw}}$ & $\mathrm{C}_{\mathrm{hw}}$ \\
\hline & $\mathrm{cm}$ & $\%$ & $\%$ & & $\% \mathrm{C}_{\mathrm{ox}}$ & $\mathrm{mg} / \mathrm{kg}$ \\
\hline \multirow[t]{3}{*}{ Humpolec L } & $0-17$ & 2.77 & 0.25 & 11.08 & 3.75 & 1040 \\
\hline & $17-49 / 69$ & 1.36 & 0.12 & 11.33 & 1.05 & 142 \\
\hline & 49/69-94 & 0.52 & 0.05 & 10.40 & 1.80 & 93 \\
\hline \multirow[t]{3}{*}{ Humpolec PP } & $0-28$ & 1.36 & 0.17 & 8.00 & 2.07 & 281 \\
\hline & $28-61$ & 0.55 & 0.05 & 11.00 & 2.11 & 116 \\
\hline & $61-118$ & 0.36 & 0.05 & 7.20 & 2.79 & 100 \\
\hline \multirow[t]{5}{*}{ LP 35} & $0-10$ & 36.61 & 1.55 & 23.62 & 4.92 & 17841 \\
\hline & $10-27$ & 19.03 & 0.83 & 22.93 & 4.92 & 12165 \\
\hline & $27-51$ & 0.89 & 0.05 & 17.80 & 3.83 & 525 \\
\hline & $51-71$ & 0.89 & 0.04 & 22.25 & 4.34 & 581 \\
\hline & $71-111$ & 0.36 & 0.02 & 18.00 & 5.86 & 305 \\
\hline \multirow[t]{4}{*}{ LP 36} & $0-8$ & 10.60 & 0.57 & 18.60 & 5.32 & 7154 \\
\hline & $8-24$ & 1.14 & 0.21 & 5.43 & 2.70 & 432 \\
\hline & $24-44$ & 0.73 & 0.04 & 18.25 & 1.08 & 150 \\
\hline & $44-58$ & 0.16 & 0.01 & 16.00 & 1.40 & 132 \\
\hline
\end{tabular}

$\mathrm{C}_{\mathrm{ox}}$ - organic carbon, $\mathrm{C}_{\mathrm{hw}}$ - hot-water extractable carbon, $\mathrm{N}_{\mathrm{t}}-$ total nitrogen

\section{SOIL ORGANIC MATTER}

The distribution of organic carbon, hot-water carbon, nitrogen and $\mathrm{C} / \mathrm{N}$ ratio within the profiles is presented in Table 8. Values of organic carbon are the highest in upper parts of the profiles but the content of soil organic matter is different. The highest values of soil organic matter were identified in forest soils in soil profiles LP 35 and LP 36, and the lowest values in the experimental field at Humpolec. The reserves of soil organic matter according to land use are (in descending order): nature protection (forest) permanent grass cover - crop agriculture. The reserves of soil organic matter can be connected with the sources of soil biomass. The content of hot-water extractable carbon is an important indicator of the state of the soil organic matter, which can compensate for the hitherto used parameters, such as humic acids, fulvic acids etc. The distribution the value of hotwater extractable carbon in \% within the profiles is different. This parameter is uniform at Humpolec PP. The values of this quality decrease to the $\mathrm{C}$ horizons at Humpolec L and LP 36. An opposite tendency was recorded in the area of LP 35. The $\mathrm{C} / \mathrm{N}$ ratio was evaluated by Orlov (1985). The $\mathrm{C} / \mathrm{N}$ value showed that the stock of $\mathrm{N}$ in the $\mathrm{A}$ and $\mathrm{O}$ horizons is low at locality LP 35 and LP 36, average at Humpolec L and high in area of Humpolec PP. The quality parameter $\mathrm{C} / \mathrm{N}$ also indicated a lower degree of decomposition of soil biomass in $\mathrm{Oa}$ and $\mathrm{Ah}$ horizons of forest soils (LP 35, LP 36). The formula $\mathrm{R}=\mathrm{BD} \times \mathrm{T} \times \mathrm{C}$ where
$\mathrm{R}$ denotes the reserves of $\mathrm{C}_{\mathrm{ox}}(\mathrm{t} / \mathrm{ha}), \mathrm{BD}$ is bulk density $\left(\mathrm{g} / \mathrm{cm}^{3}\right), \quad \mathrm{T}$ is thickness of the layer $(\mathrm{cm})$ and $\mathrm{C}$ is $\mathrm{C}_{\mathrm{ox}}$ content for respective interval (\%), was used for the calculation of the reserves of soil organic matter at individual localities. Reserves of organic carbon ( $\mathrm{t} / \mathrm{ha}$ ) in the upper $25 \mathrm{~cm}$ are as follows at the studied localities: Humpolec L - 65.60; Humpolec PP - 54.06; LP 35 - 217.56; LP 36 - 92.09. The results obtained in this study indicate that the reserves of $\mathrm{C}_{\mathrm{ox}}$ correspond to the source of aerial and below-ground biomass and also to the type of land use. Reserves of soil organic matter are the highest in forests and the lowest in agricultural areas.

\section{MINERALOGY}

Mineral composition of the fraction $<0.001 \mathrm{~mm}$ is given in Table 9. The X-ray diffractograms of the clay fraction from $\mathrm{Bw}$ horizons are given in Figure 1 (Humpolec PP - paragneiss) and Figure 2 (LP 36 granite). Haplic Cambisol on paragneiss in agricultural landscape conditions (Humpolec PP) has a high content of illite and kaolinite. The contents of chlorite, smectite and interlayered illite-vermiculite are smaller. The smaller content of feldspars is typical for the soils developed on paragneiss. A very similar mineral composition, except for the elevated chlorite content and the absence of smectite in all profiles, was found in Haplic Cambisol on cordierite paragneiss in the case of permanent grass cover (Humpolec L). This fact can be explained by the presence of cordierite 
Table 9 Mineral composition of the fraction $<0.001 \mathrm{~mm}$.

\begin{tabular}{|c|c|c|c|c|c|c|c|c|c|c|c|c|}
\hline \multirow[t]{2}{*}{ Locality } & Depth & A & $\mathrm{Ch}$ & I & $\mathrm{I}-\mathrm{S}$ & $\mathrm{I}-\mathrm{V}$ & $\mathrm{K}$ & $\mathrm{F}$ & $\mathrm{L}$ & $\mathrm{P}$ & Q & $\mathrm{S}$ \\
\hline & $\mathrm{cm}$ & $\%$ & $\%$ & $\%$ & $\%$ & $\%$ & $\%$ & $\%$ & $\%$ & $\%$ & $\%$ & $\%$ \\
\hline \multirow[t]{3}{*}{ Humpolec L } & $0-17$ & 0 & 15 & 26 & 0 & 14 & 17 & 4 & 0 & 4 & 20 & 0 \\
\hline & $17-49 / 69$ & 0 & 21 & 26 & 0 & 0 & 17 & 3 & 0 & 3 & 30 & 0 \\
\hline & 49/69-94 & 0 & 17 & 18 & 0 & 7 & 10 & 4 & 0 & 2 & 42 & 0 \\
\hline \multirow[t]{3}{*}{ Humpolec PP } & $0-28$ & 0 & 5 & 32 & 0 & 0 & 25 & 5 & 0 & 4 & 29 & 0 \\
\hline & $28-61$ & 0 & 2 & 25 & 0 & 2 & 21 & 5 & 0 & 4 & 40 & 1 \\
\hline & $61-118$ & 0 & 0 & 16 & 0 & 6 & 24 & 9 & 0 & 4 & 32 & 9 \\
\hline \multirow[t]{5}{*}{ LP 35} & $0-10$ & nd & nd & nd & nd & nd & nd & nd & nd & nd & nd & nd \\
\hline & $10-27$ & 0 & 17 & 10 & 0 & 0 & 22 & 8 & 0 & 13 & 30 & 0 \\
\hline & $27-51$ & 1 & 3 & 4 & 11 & 0 & 13 & 6 & 1 & 5 & 29 & 28 \\
\hline & $51-71$ & 0 & 8 & 2 & 8 & 0 & 8 & 17 & 0 & 13 & 45 & 0 \\
\hline & $71-111$ & 0 & 8 & 2 & 0 & 0 & 10 & 15 & 1 & 15 & 50 & 0 \\
\hline \multirow[t]{4}{*}{ LP 36} & $0-8$ & 0 & 5 & 2 & 0 & 0 & 3 & 7 & 0 & 6 & 79 & 0 \\
\hline & $8-24$ & 0 & 22 & 2 & 0 & 0 & 6 & 9 & 0 & 7 & 55 & 0 \\
\hline & $24-44$ & 0 & 36 & 7 & 0 & 0 & 9 & 8 & 0 & 6 & 34 & 0 \\
\hline & $44-58$ & 0 & 11 & 10 & 2 & 0 & 6 & 14 & 2 & 13 & 41 & 0 \\
\hline
\end{tabular}

A - amphibole, $\mathrm{Ch}$ - chlorite, I - illite, I-S - illite-smectite, I-V- illite-vermiculite, $\mathrm{K}$ - kaolinite, F- K-feldspar, $\mathrm{L}$ - lepidocrocite, $\mathrm{P}$ - plagioclase, $\mathrm{Q}$ - quartz, $\mathrm{S}$ - smectite, nd - not determined

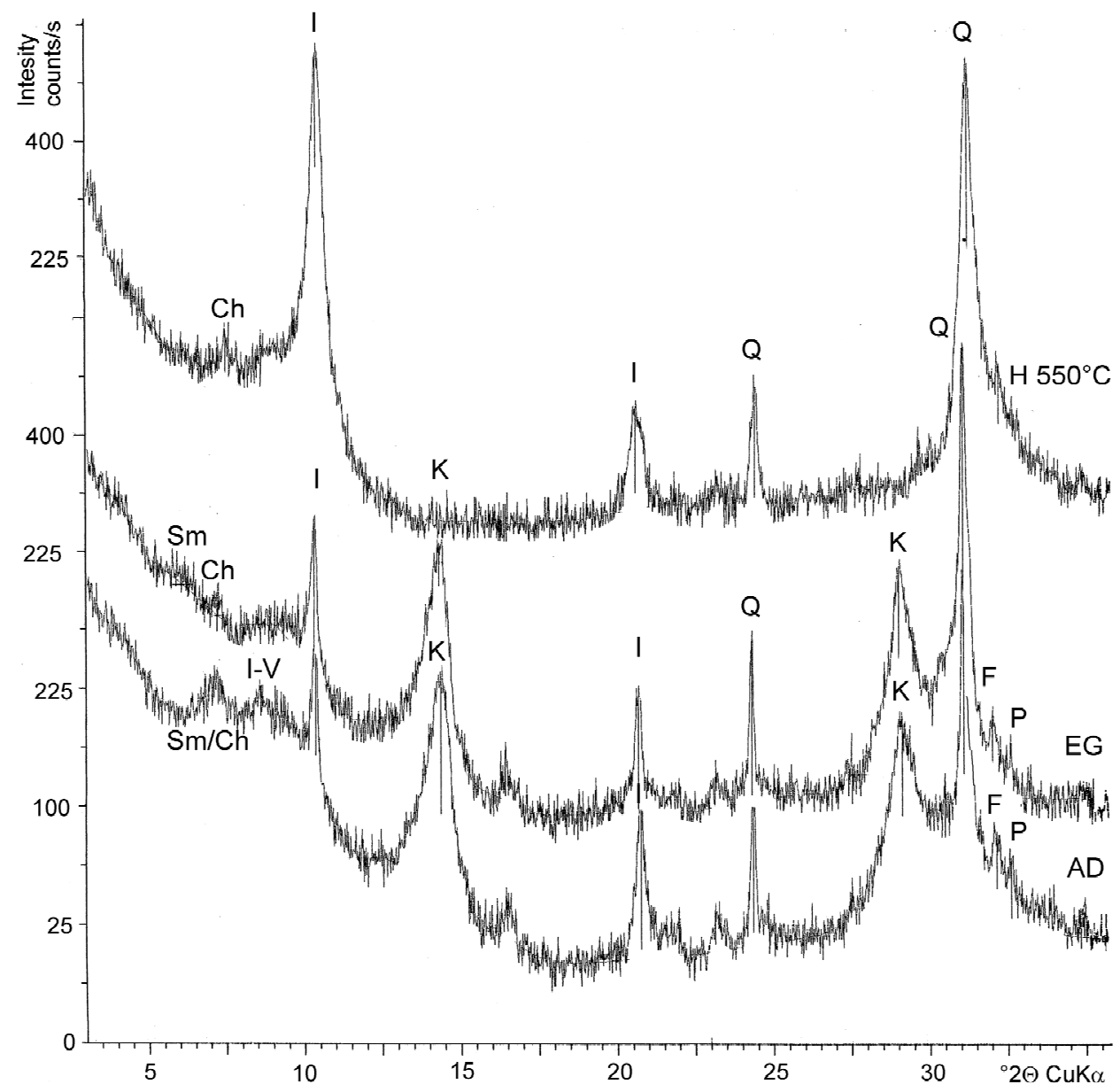

Fig. $1 \mathrm{X}$-ray diffractogram of clay fraction from the Bw horizon developed on paragneiss (Humpolec PP).

AD - air-dried, EG - ethylene glycol solvated, H - heating, Ch - chlorite, I - illite, I-V -illitevermiculite, $\mathrm{K}$ - kaolinite, $\mathrm{F}$ - K-feldspar, $\mathrm{P}$ - plagioclase, $\mathrm{Q}$ - quartz, $\mathrm{S}$ - smectite 


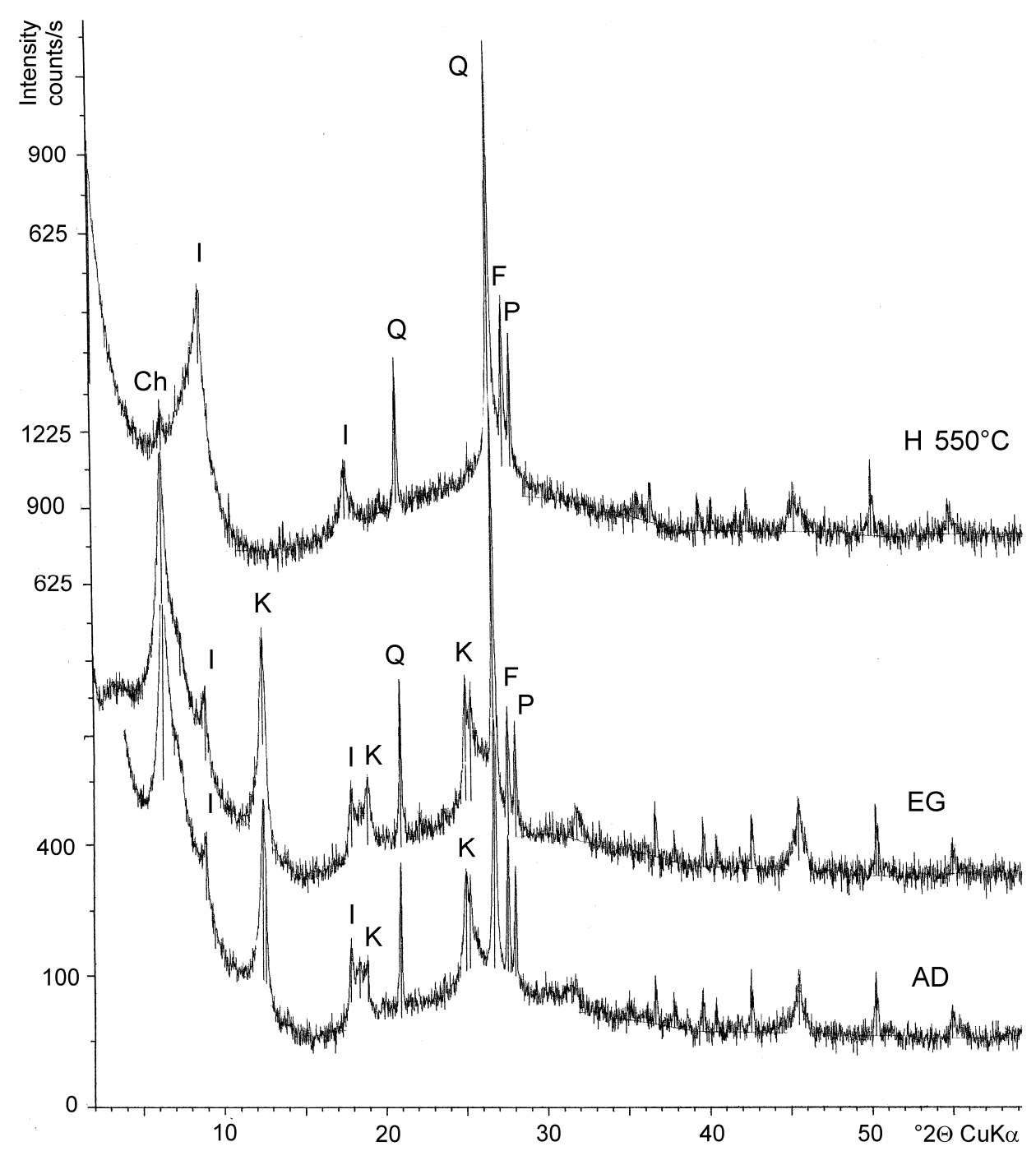

Fig. 2 X-ray diffractogram of clay fraction from the Bw horizon developed on granite (LP 36).

$\mathrm{AD}$ - air-dried, EG - ethylene glycol solvated, $\mathrm{H}$ - heating, $\mathrm{Ch}$ - chlorite, I - illite, $\mathrm{K}$ - kaolinite, $\mathrm{F}$ - Kfeldspar, P - plagioclase, Q - quartz

paragneiss, where cordierite weathers into pinite (mixture of sericite and chlorite). The localities of Humpolec L and Humpolec PP have very similar contents of quartz, feldspars, kaolinite and illite. These mineral compositions correspond to the development of soils on paragneiss. Dystric Cambisol on the Jevany type of granite (LP 35) is a typical example of soil developed on granite with the presence of quartz and higher content of feldspar together with their weathering products such as kaolinite, illite and chlorite. Transitional types of transformation, such as smectite and interlayered illite-smectite, are present in this soil profile. AhBw and $\mathrm{C}$ horizons contain a small portion of lepidocrocite. Dystric Cambisol on the Řiccany type of granite (LP 36) contains chloritized biotite and partly argillized feldspar which is reflected by the high content of chlorite in the soil profile. The alteration of biotite into chlorite was described by Eggleton and Banfield (1985). Presence of other clay minerals such as kaolinite, illite and interlayered illite-smectite is smaller. C horizon contains a small portion of lepidocrocite.

In contrast to soils developed on granite, soils on paragneiss have high contents of illite a kaolinite and lower contents of K-feldspar and plagioclase. This mineral composition showed that the soils developed on paragneiss show a higher degree of weathering of the parent material and also a higher intensity of the development of Bw horizon.

\section{CONCLUSION}

The main pedogenic process in soils developed on paragneiss and granite under very similar climatic conditions in southeastern Bohemia is the formation of the cambic horizon.

Soils developed on paragneiss in the Humpolec area were classified as Haplic Cambisols. Soils developed on granite in the Voderradské bučiny National Nature Reserve were classified as Dystric Cambisols. 
The particle size distributions, physical, chemical and mineral properties of Cambisols were influenced to a variable degree by the type of parent material.

Physical properties of soils are controlled by the type of parent material and by the type of land use, especially in the upper part of soil profiles (Oa and A horizons). The best physical properties are displayed by soils with permanent grass cover.

Haplic Cambisols developed on paragneiss have more favourable chemical properties $(\mathrm{pH}$, cation exchange capacity, base saturation) than Dystric Cambisols on granite.

The content and quality of soil organic matter are connected with the type of vegetation and land use. Soils in the forest show the highest contents and reserves of organic matter, which is connected with the presence of relatively high amount of litter. The quality parameter $\mathrm{C} / \mathrm{N}$ indicated a lower degree of decomposition of soil biomass in $\mathrm{Oa}$ and $\mathrm{Ah}$ horizons of forest soils (LP 35, LP 36), and very similar in the case of permanent grass cover and arable soil.

Specific pedogenic processes of litter formation operate in the forest. Agroturbation is typical for arable soil. Soils developed on paragneiss are characterized by a stronger weathering of parent material than the soils on granites. The thickness and intensity of formation of cambic horizons is influenced by the type of parent material. Soils developed on paragneiss have a better developed $\mathrm{Bw}$ horizon than the soils on granites.

\section{ACKNOWLEDGMENTS}

This study was supported by grant project 526/08/0434 from the Czech Science Foundation and the RVO 67985831 (Institute of Geology AS CR, v.v.i.).

\section{REFERENCES}

Balík, V.: 2001, Checklist of the Soils and Moss T estate Amoebae (Protozoa, Rhizophoda) from the National Nature Reserve Voděradské bučiny (Czech Republic), Journal of the National Museum (Prague), Natural History Series, 170, No. 1-4, 91-104.

Chlupáč, I., Brzobohatý, R., Kovanda, J. and Stráník, Z.: 2002, Geological history of the Czech Republic, Academia, Praha, 436 pp., (in Czech).

Dane, J. and Topp, G.C.: 2002, Methods of soil analysis, Part 4, Physical methods, Soil Science Society of America Book Series 5. Inc. Madison, Wisconsin, $1692 \mathrm{pp}$.

Eggleton, R.A. and Banfield, J.F.: 1985, The alteration of granitic biotite to chlorite, Am. Miner., 70, No. 9-10, 902-910.

Ghani, A., Dexter, M and Perrott, K. W.: 2003, Hot-water extractable carbon in soils: a sensitive measurement for determining impacts of fertilisation, grazing and cultivation. Soil Biol. Biochem., 35, No. 9, 12311243. DOI: $10.1016 / \mathrm{S} 0038-0717(03) 00186-\mathrm{X}$

IUSS Working Group WRB: 2007, World Reference Base for Soil Resources 2006, First update 2007, World Soil Resources Reports 103, FAO, Rome, 116 pp.
Jackson, M.L: 1975, Soil chemical analyses - Advanced course, Second Edition. 10 th printing. Published by author. Madison, Wisconsin, $386 \mathrm{pp}$.

Jahn, R., Blume, H. P., Asio, V.B., Spaargaren, O. and Schad, P.: 2006, Guidelines for soil description, 4th edition. FAO, Rome, $97 \mathrm{pp}$.

Kodešová, R., Rohošková, M. and Žigová, A.: 2009, Comparison of aggregate stability within six soil profiles under conventional tillage using various laboratory tests, Biologia, 64, No. 3, 550-554. DOI: $10.2478 / \mathrm{s} 11756-009-0095-6$

Kozák, J., Němeček, J., Borůvka, L., Kodešová, R., Janků, J., Jacko, K. and Hladík, J.: 2010, Soil Atlas of the Czech Republic, Czech University of Life Sciences, Prague, $150 \mathrm{pp}$.

Lhotský, J.: 2000, Soil compaction and measures against it. Studijní infornace, Rostlinná výroba, 7, Ústav zemědělských a potravnářských informací, Praha, 63 pp., (in Czech).

Minařík, L., Žigová, A., Bendl, J., Skřivan, P. and Št’astný, M.: 1998, The behaviour of rare-earth elements and Y during the rock weathering and soil formation in the Řičany granite massif, Central Bohemia, Sci. Total Environ, 215, No. 1-2, 101-111.

Munsell, A.H.: 2000, Munsell soil color charts, Revised washable edition. New Windsor, New York, 9 color charts, $10 \mathrm{pp}$.

Němec, D.: 1978, Genesis of aplite in the Říčany massif, central Bohemia. Neus Jahrbuch für Mineralogie, Abhandlungen, 132, No. 3, 322-339.

Němeček, J.: 1974, Cambisols, Rostl. Vyroba, 20, No. 5, 463-474.

Orlov, D. S.: 1985, Soil chemistry, MGU, Moskva, 376 pp., (in Russian).

Palivcová, M.: 1965, The Central Bohemian pluton - a petrographic review and an attempt at a new genetic interpretation. Krystalinikum, 3, 99-131.

Řepová, A.: 1983, Soil micromycetes of foerest reserve "Voděradské bučiny" in Central Bohemia, Čes. Mykol., 37, No. 1, 19-34.

Sirový, V.: 1974, Clay mineral formation and alteration in some brown forest soils. Rostl. Vyroba, 20, No. 5, 451-459.

Stoops, G.: 2003, Guidelines for analysis and description of soil and regolith thin sections, Soil Science Society of America, Inc. Madison, Wisconsin, 184 pp.

Taboada, T. and Garcia, C.: 1999, Smectite formation produced by weathering in a coarse granite saprolite in Galicia (NW Spain), Catena, 35, No. 2-4, 281-290.

Tardy, Y., Bocquier, G., Paquet, H and Millot, G.: 1973, Formation of clay from granite and its distribution in relation to climate and topography, Geoderma, 10, No. 4, 271-284

Valla, M., Kozák, J., Němeček, J., Matula, S., Borůvka, L. and Drábek, O.: 2002, Laboratory Soil Science. Česká zemědělská univerzita, katedra pedologie a geologie AF, Praha, 151 pp., (in Czech).

Žigová, A., Št'astný, M., Krejčová, J. and Hájek, P.: 2007, Characterization of anthropogenic influence on the soil cover on selected localities of Prague, Acta Geodyn. Geomater. 4, No. 3 (147), 39-49.

Žigová, A., Št’astný, M. and Krejčová, J.: 2010, Mineral composition of the clay fraction in soils with a cambic horizon in the Czech Republic. Acta MineralogicaPetrographica, Abstract Series, 6, 648. 